\title{
Changing hotel location patterns in Ekurhuleni, South Africa's industrial workshop
}

\author{
Jayne M. Rogerson
}

Jayne M. Rogerson, University of Johannesburg, Faculty of Science, School of Geography, Environmental Management \& Energy Studies, South Africa (jayner@uj.ac.za)

\begin{abstract}
The accommodation sector is of central importance to research on urban tourism. A number of studies seek to understand the location of hotels in urban areas. This article contributes to the limited scholarship on hotel location in African cities. Under investigation is hotel development in Ekurhuleni, one of South Africa's newest metropolitan areas with a strong tradition of mining and industrial activities. This is a non-traditional tourism destination where until recently leisure tourism was not a component of the local economy. In terms of tourism development Ekurhuleni has expanded its share of business tourism as a result of its geographical location in South Africa's economic heartland. Importantly, business tourism has been driven by the location in Ekurhuleni of OR Tambo Airport, South Africa's major international gateway airport. Between 1990 and 2010 this investigation shows that the local hotel economy of Ekurhuleni has been transformed. One aspect of restructuring has been the collapse of the low quality liquor dominated hotel which was numerically the major accommodation type of the pre-1990 period. The booming business tourism economy caused new investments and hotel property developments in medium-size and high quality four and five star hotel establishments. Growth has clustered geographically in and around the international airport which is the key contemporary locational influence for hotel location in this investigation.
\end{abstract}

Keywords: accommodation, urban tourism, hotel location, airport hotels, Ekurhuleni; Gauteng

\section{Introduction}

An expanding body of scholarship addresses various topics of tourism in urban destinations. One issue of particular importance is research around accommodation services. In the United States Raitz \& Jones (1988) consider hotels as the historical cornerstone of urban development and marking the early business and social core of cities. In the historical landscapes of colonial cities, such as Colombo or Singapore, 'European hotels' became a common phenomenon of the built environment offering high standards of accommodation and functioning as comfort zones and localizers of modernity (Peleggi, 2012). According to Jansen-Verbeke (1986) all commercial forms of accommodation establishments constitute temporary homes away from home for tourists and focal points from which most tourism activity begins in any destination. Shoval et al. (2011: 1594) observe tourists commence "their day by leaving the hotel, possibly returning to the hotel intermittently during the day before engaging the destination once more, and finished their day by returning to the hotel to sleep". With rising demand for accommodation services to cater to tourist requirements the provision of commercial forms of accommodation emerged and consolidated as a vital service sector activity in cities. Tourism accommodation impacts urban form, structure and morphology as well as the image of cities (Timothy \& Wall, 1995). Wall et al. (1985) point out that the structures built to satisfy the needs of tourists are increasingly visible features of the urban landscape. As hotels constitute the essential facilities to support urban tourism the growth and success of cities as tourism destinations is associated strongly with the establishment and expansion of the accommodation service sector (Jansen-Verbeke, 1986; Law, 1992, 1993; Yang et al., 2014). 
According to Williams (2014) the largest amount of international research conducted on the accommodation sector is pursued from the perspective of hospitality management rather than tourism studies. For international hospitality students the hotel represents a core focus for research surrounding management issues. Timothy \& Teye (2009) point out that existing scholarly work concentrates on the business management side of hotels with a clustering of studies around marketing, human resources, facilities, guest satisfaction, reservation and information systems, housekeeping, catering, and budgeting. This trend is in evidence from reviews undertaken of tourism studies about sub-Saharan Africa (Rogerson, 2013a). Once again, it is revealed most accommodation research centres upon questions of service management, hospitality resource training, or customer satisfaction issues (Nunkoo et al. 2014). Outside of these considerations only sporadic research so far has been undertaken on the position of accommodation in the African tourism economy (Ernst \& Young, 2011). Furthermore, given the rural emphasis in African tourism research as a whole, the urban accommodation sector is a knowledge theme that is particularly overlooked in Africa (Rogerson \& Rogerson, 2011).

In terms of the role of hotels in tourism economies the location decision is a matter of critical concern (Egan \& Nield, 2000; Medlik \& Ingram, 2000; Adam \& Amuquandoh (2013). Among others the works of Baum and Mezias (1992) stress that location is one of the most critical determinants of a tourist's decision to purchase accommodation services. As tourism development is uneven, however, spatial variations occur in the demand for hotel services at the international, national and intra-urban scales of analysis. At the international level, aspects of the globalization of the hotel industry have been scrutinized in works produced by Niewiadomski (2013a, 2013b) for Europe, by Zhang et al. (2012) for Asia and by Rogerson (2014a) for hotel chain development in Africa. At the national scale of analysis research on the spatial distribution of accommodation services has been undertaken variously for USA (Van Doren \& Gustke, 1982), Spain (Pearce \& Grimmeau, 1985; Barke \& France, 1986), China (Zhang et al. 2012) and South Africa (Rogerson, 2013b, 2013c).

The focus in this investigation is hotel development and location decisions at the urban scale. The case study research is centred on the South African metropolitan area of Ekurhuleni which is situated in Gauteng province, the country's economic heartland. An analysis is conducted of the changing location patterns of hotel establishments in Ekurhuleni from 1990 to 2010. The research discloses different structural and location issues to those which have been revealed either in Johannesburg, the country's largest and most vibrant metropolitan area (Rogerson, 2014b) or South Africa's major coastal centres of Cape Town, Durban and Port Elizabeth (Rogerson, 2012a). At one level this study is a contribution to the growing debates and scholarship taking place around uneven tourism development in South Africa, urban tourism and landscapes of hotel development in particular (see eg. Rogerson \& Visser, 2007; Rogerson, 2010, 2011a, 2011b; Rogerson \& Kotze, 2011; Rogerson \& Visser, 2011; Rogerson \& Sims, 2012; Rogerson, 2012a, 2012b, 2013d, 2013e, 2014b; Ferreira \& Boshoff, 2014). More broadly, the research seeks to extend the corpus of international scholarship both in the contexts of developed and developing countries which aims to understand and interpret the evolution, changes, and locational logic of urban hotels (see Arbel \& Pizam, 1977; Wall et al., 1985; Oppermann et al. 1996; Dokmeci \& Balta, 1999; Begin, 2000; Shoval \& Cohen-Hattab, 2001; Shoval, 2006; Shoval et al., 2011; Adam, 2012; Adam and Mensah, 2013; Yang et al., 2014).

\section{The Intra-Urban Location of Hotels}

In an important contribution, Egan \& Nield (2000: 613) pointed out the sparseness of research on the intra-urban location of hotels. Likewise, Shoval \& Cohen-Hattab (2001) assert that as compared to other urban functions such as housing, industry, commerce or offices, 
research on the location of the hotel sector is relatively limited. Nevertheless, some empirical investigations on the spatial structure of accommodation in cities have been completed. It is observed most existing work investigates hotel location in 'tourist-historic' cities either in Europe (Ashworth \& Tunbridge, 1990; Urtasan \& Gutiérrez, 2006) or Asia (Timothy \& Wall 1995). Beyond these areas other contexts where the geography of urban accommodation has been scrutinised include Canada (Wall et al., 1985), China (Bégin, 2000; Yang et al. 2012), Israel (Arbel \& Pizam, 1977; Shoval \& Cohen-Hattab, 2001; Shoval, 2006), Malaysia (Oppermann, et al. 1996), Turkey (Dökmeci \& Balta, 1999), and USA (Baum \& Mezias, 1992). In sub-Saharan Africa empirical work now is available for certain cities in both Ghana (Adam, 2012, 2013, Adam \& Amuquandoh, 2013; Adam \& Mensah, 2013) and South Africa (Rogerson, 2012b, 2014b).

From the findings of several international studies it is evident that tourism accommodation is not evenly or randomly distributed throughout cities rather it is confined in spatial clusters to certain specific locations (Yang et al., 2014). In understanding patterns of urban hotel location one influential early work was that by Ritter (1986: 355) who remarked that "Hotel location seems to be a singularly neglected field of tourism research and, we might add, in locational theory". Based upon empirical work of hotel development in Nuremberg, Germany from the start of the $19^{\text {th }}$ century Ritter (1986) forwarded a model for the evolution of hotels in tourist centres. The model stressed that the location of hotels was associated closely with the dominant form of transportation technology of the time. Prior to the dominance of railways, hotels in inland urban centres were developed mainly in the city centre and those on lakes or rivers tended to situate along waterfronts. With the appearance of railways the patterns of hotel development shifted and became concentrated around railway stations. However, the rise of the automobile era precipitated "a decline in the importance of hotel districts close to railroad stations and to the construction of large hotels on the outskirts of the city in close proximity to the 'ring road' and access routes leading from the outskirts to the city centre” (Shoval \& Cohen-Hattib, 2001: 911). More recent trends in hotel location are unaccounted for by the Ritter (1986) model and include the clustering of hotels beyond the city centre in the environs of airports, trade fair sites and business convention centres (Van Doren \& Gutske, 1982; Wall et al., 1985; Medlik \& Ingram, 2000; Shoval, 2006; McNeill, 2009).

The analysis of Ashworth \& Tunbridge (1990) on tourism accommodation patterns in historic cities spawned a similar model of urban hotel location patterns for the 'tourist-historic city'. The model demarcates the city into distinct zones where specific hotel clusters occur. Specifically, Ashworth \& Tunbridge (1990) differentiate six kinds of hotel locations, namely: (1) historic city locations, (2) railway station locations, (3) along main access routes (4) clusters of small and medium hotels in 'nice' locations, (5) large modern hotels in a transition zone between the CBD and historic city, and (6) the urban periphery including along motorways and airport transport interchanges. Each of these zones corresponds to a particular hotel profile. Other research adapts classic land use theory models such as that of von Thünen to interpret the question of urban hotel location. In applying a concentric land use model based on the principle of land rent curves and representing a derivative of the classic agricultural land use model Shoval (2006) situates the hotel district in the city centre and more specifically between the CBD and a zone of commerce.

As is detailed elsewhere (Rogerson, 2014b), in examining contemporary scholarship on the intra-urban location of hotels two broad sets of locational determinants must be recognised. The first are location attributes concerning accessibility, agglomeration advantages, and general level of urban development. In particular, Yang et al. (2012: 676) argue that accessibility is considered a prime factor as "hotels are keen on locations that are proximate to their potential markets because hotels seek for increased demand from potential 
guests”. Agglomeration is viewed another critical dimension of hotel location because in most cities hotels cluster in certain areas. Within compact and well-defined 'hotel districts' there are high levels of localized competition as exemplified by the case of Manhattan, New York (Baum \& Mezias, 1992). In such hotel districts Urtasun \& Gutiérrez (2006) maintain entrepreneurs confront important location choices for new establishments, whether to locate a new hotel property close to competitors or be differentiated in geographic and product space. Both Medlik \& Ingram (2000) and Yang et al. (2012) point to the significance for hotel location decision-making of certain individual hotel characteristics. The most notable characteristics for interpreting the intra-urban location of hotels relate to size of establishment, quality as indicated by star rating, and market segment. It is argued that hotels of different size, star rating and those focused on different market segments may have different influences upon their location choice (Yang et al., 2012).

Overall, it is clear from several studies that hotel location patterns evolve through time with shifting patterns of urban development (Wall et al., 1985; Timothy \& Wall, 1995; Oppermann, et al. 1996; Begin, 2000; Shoval \& Cohen-Hattib, 2001; Urtasun \& Gutiérrez, 2006; Yang et al. 2014). Indeed, decision-making about hotel location in urban areas is highly contingent upon shifting patterns of city development which inevitably recasts urban structures over time. In addition, the importance of location attributes varies between individual cities (Rogerson, 2014b). Critical influences upon the geography of hotels in specific cities relate to the morphology, history and various economic functions of the particular city in question, as well as the particular type of urban tourism, whether focussed on leisure or business tourism products.

It is against this background that attention moves in the next section to the case study of hotel development in the South African metropolitan area of Ekurhuleni. Recent surveys of trends in South African urban research show the emphasis upon Cape Town by local and international urban scholars (Visser, 2013; Visser \& Rogerson, 2014). As compared to cities such as Cape Town, Durban or Johannesburg, the metropolitan area of Ekurhuleni is a relatively under-researched urban centre. The analytical focus on changing hotel development in Ekurhuleni is on the period 1990 to 2010 which is highly significant for tourism development in South Africa as a whole. Importantly, it includes the 1994 democratic transition which ushered in a phase of rapid growth of both international and domestic tourism following the country's re-entry into the global economy after several years of economic boycotts and sanctions (Rogerson \& Visser, 2004). The closing year for this study 2010 is also a critical landmark for the tourism industry of South Africa as it marks the country's hosting of the FIFA Soccer World Cup.

\section{The Ekurhuleni Case Study}

The analysis of Ekurhuleni is organised into three uneven subsections of material. First, a brief background is given of the establishment and changing economic base of this metropolitan area. The second section discusses data issues regarding the hotel economy. The third and major section examines the changing structure of the Ekurhuleni hotel economy between 1990 and 2010 and subsequently unpacks the intra-metropolitan patterns of hotel developments.

\section{Locating The Metropolitan Area of Ekurhuleni}

The Ekurhuleni metropolitan area was formed as a unified entity only after the country's municipal elections which were held in December 2000. It is thus one of South Africa's newest metropolitan areas (Rogerson, 2005). The new metropolitan area is organized around the regions previously known as the East Rand and Far East Rand. However, unlike other newly constituted South African metropolitan areas, Ekurhuleni does not represent the 
extension of an existing city. Instead, it was an amalgamation of several long-established towns, namely the six East Rand centres of Alberton, Benoni, Boksburg, Edenvale, Germiston and Kempton Park which merged with the three Far East Rand centres of Brakpan, Nigel and Springs (Figure 1). Prior to the 1970s these areas were a bastion of the gold mining industry. Structural economic change linked to the decline of gold mining and the rise of manufacturing resulted in these regions subsequently reborn and restyled as the country's national industrial workshop or South Africa's Ruhr (Bloch, 1993; Centre for Development and Enterprise, 1997; Roberts, 2006). Despite a shakeout of the manufacturing economy and considerable job losses which occurred during the 1990s the industrial sector remained at the heart of formal employment in Ekurhuleni by the early 2000s (Rogerson, 2006). The key components of manufacturing in terms of value-added were metal products, machinery and household appliances, fuel, petroleum, chemical and rubber products, and food, beverages and tobacco products (Rogerson, 2005).

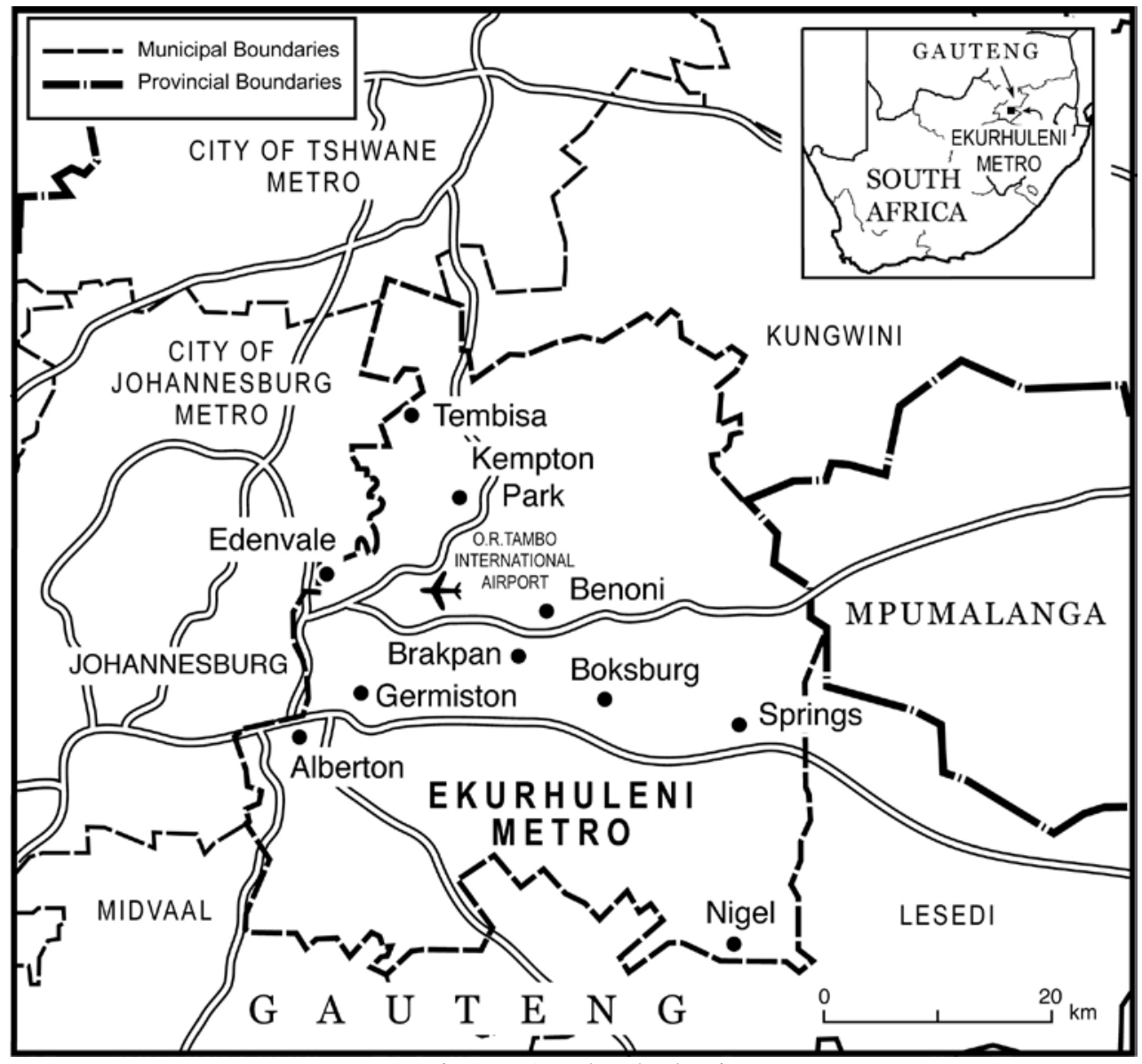

Figure 1: Ekurhuleni

By 2009 Ekurhuleni contributed an estimated 9 percent of gross value added which made it the third most important metropolitan area in South Africa in terms of economic output (South African Cities Network, 2011). As compared to Cape Town or Johannesburg, Ekurhuleni is distinguished by the continued strength and significance of manufacturing in the local economy. Indeed, the report by South African Cities Network (2011: 36) describes Ekurhuleni as "predominantly a manufacturing centre, with a diverse industrial base". Leading sectors of concentration were identified as in the following activities, viz., chemicals, rubber and plastics; metal products and machinery; electrical machinery; radio, television and instruments; and transport and storage. 
The area's added competitive strengths in transport and storage are inseparable from the fact that Ekurhuleni is the location of South Africa's major international airport and Africa's busiest airport, namely OR Tambo Airport. Diversification of the local economy from manufacturing has been made possible by the attractions of the airport for tourism developments which have included the opening of casinos, conference centres and hotels. Ekurhuleni is therefore a non-traditional tourism destination as its major tourism assets are for attracting business rather than leisure tourists. The economy of business travel and tourism is anchored around the OR Tambo international airport. This flagship gateway airport for South Africa experienced post-2000 massive infrastructural investment for upgrading and expansion which was triggered by the award to South Africa of the 2010 FIFA World Cup. Future development planning for Ekurhuleni aims to capitalise further on this asset and on the city's logistical advantages. Flagship proposals surround planning for Ekurhuleni to become the first 'aerotropolis' in Africa (Hancock, 2011; Smith, 2013).

\section{Data and Sources}

The analysis of the growth and changing patterns of hotels in Ekurhuleni is part of a wider investigation of the structural and spatial changes which have reconfigured the South African hotel industry over the period 1990 to 2010 (Rogerson, 2013a, 2013b). In South Africa no official record of registered hotels is maintained. The national department of tourism acknowledges that the country "lacks an adequate data base of the tourism supply side" (Department of Tourism, 2011: 15). Accordingly, the data in this analysis derives from a comprehensive national audit, compiled by the author, of all hotels in South Africa for the two time periods of 1990 and 2010.

The challenging task of building a complete database involved the triangulation of a range of different hotel listings. At the core of the 1990 base was the 1989 SATOUR listing of hotels which was updated by cross-checks with other 1990 directory listings. The 2010 audit was undertaken by triangulating information from several different hotel listings. Among these were the lists of the Tourism Grading Council of South Africa, AA Accommodation guide, lists of leading hotel chains and hotels listed by local tourism boards. In addition to published listings a comprehensive internet search was undertaken of accommodation search engines including; SA Venues, Where To Stay, Sleeping Out, Solomon Guide, Safari Now, The Portfolio Collections, Exclusive Getaways, Rooms for Africa, SA Cheap Hotels and Country Roads. This process resulted in the building up of a data set for all urban centres.

The two lists were cross-checked in order to ascertain if existing hotels were births (new properties in 2010 not in existence in 1990), deaths (establishments listed in 1990 but not in operation in 2010) or 'stayers'. In this respect considerable care was taken to cross-check addresses of hotel establishments in 1990 and 2010 in order to capture changes which often were the result of corporate take-overs or the repositioning of hotels within certain hotel group portfolios which caused name changes. The final database incorporates an information record for each hotel establishment giving for 1990 and 2010, its province, town or city, hotel name, street address, size (number of rooms), and star grading.

\section{The Growth and Location of Hotels in Ekurhuleni}

Before addressing the growth and shifts of the hotel economy in Ekurhuleni between 1990 and 2010 a brief contextual background is needed on the changing nature of the South African hotel industry. It must be understood that until the late 1980s the majority of hotels in South Africa were geared to service only the market of (white) domestic tourists rather than standards of international tourism. One distinguishing feature of the historical development of the national hotel industry was its close relationship to liquor selling. The legislative framework for the $20^{\text {th }}$ century growth of the South African hotel industry was set by liquor 
legislation and, as a consequence, a large segment of the hotel industry operated primarily as liquor rather than accommodation outlets (Rogerson, 2011). The legislation resulted in the proliferation of small so-called hotels of sub-economic size which were located irrespective of the need for accommodation. Under the 1928 Liquor Act licensees of existing bars in urban areas were forced to provide ten bedrooms in order to secure a liquor license. Walker (1977: 9) states "the conditions that the licensees had to meet were largely physical with little regard being given to the service aspect, and all new licensees carried the obligation to build an 'hotel'”. With limited funds available to individual licensees the outcome was the takeover of the hotel sector by alcohol interests which supplied finance to hoteliers through the tied house system. The consequence was "a host of haphazardly sited 'mini-hotels with 'maxi-bars'” (Walker, 1977: 10). This was a result of the tied house system and that the prime function of South African hotels was liquor selling with the function of accommodation provision relegated to secondary status (Rogerson, 2011).

The marriage of the hotel industry to liquor selling shaped the essential character of the national hotel industry from the 1920s to the late 1960s. Only from that time was there an element of the hotel economy that started to focus on accommodation as its core service (Rogerson, 2011). With legislative changes in the late 1960s there occurred a gradual shift away from liquor dominance to the emergence of a modern hotel sector in South Africa which centred upon the supply of accommodation services for profitable purposes. With the establishment and growth of large domestic hotel chains from the 1970s and 1980s the South African hotel industry became more differentiated as international standard hotels were constructed (Rogerson, 2013b, 2013c).

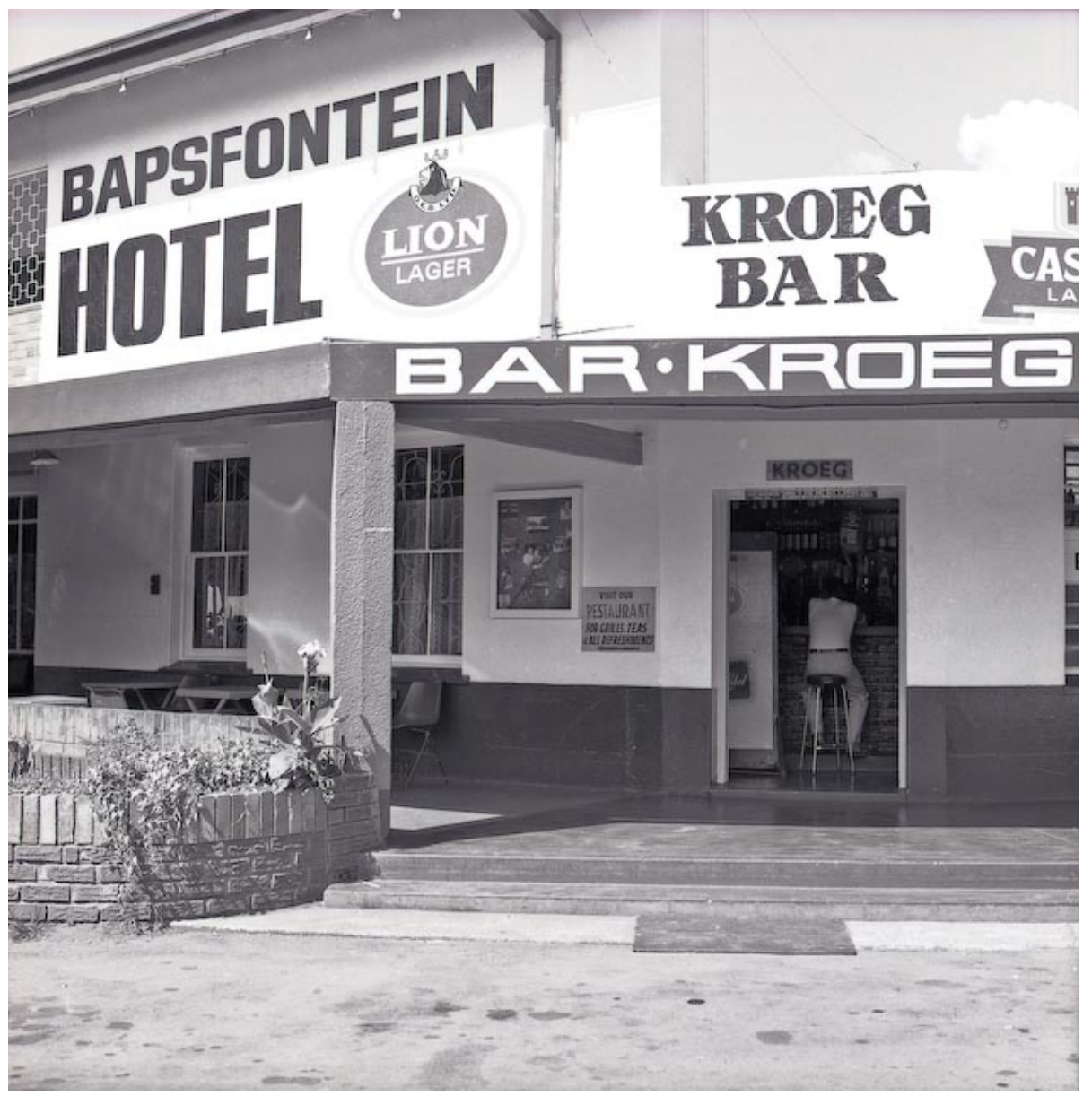

Figure 2: The Liquor Dominated Hotel in Bapsfontein, which subsequently became part of Ekurhuleni. 
These new forms of hotel development were, however, mainly concentrated in the country's major cities of Johannesburg, Durban, and Cape Town. At this time the mining and industrial settlements of the East Rand and Far East Rand were not favoured destinations for such international standard hotels. It must be understood therefore that much of the early development of hotels in the mining and industrial towns that later would form the metropolitan area of Ekurhuleni was inseparable from the activity of liquor selling. By 1990 the majority of the so-called 'hotels' in towns such as Alberton, Brakpan, Benoni, or Springs were the liquor-dominated small establishments which were the legacy of early legislation which had shaped the contours of national hotel development. Figure 2 shows one typical example from the metropolitan area of Ekurhuleni, the Bapsfontein Hotel.

Table 1: Ekurhuleni Hotel Economy 1990 and 2010

\begin{tabular}{llll}
\hline & $\mathbf{1 9 9 0}$ & $\mathbf{2 0 1 0}$ & Net Change \\
\hline No of Hotels & 47 & 45 & -2 \\
No. of Rooms & 1,539 & 4,386 & $+2,847$ \\
\hline
\end{tabular}

Table 2: Hotel Stock Property Turnover in Ekurhuleni, 1990-2010

\begin{tabular}{lll}
\hline Location & $\begin{array}{l}\text { \% 1990 Hotel Property Stock Not } \\
\text { Existing in } \mathbf{2 0 1 0}\end{array}$ & $\begin{array}{l}\text { \% 2010 Hotel Property Stock } \\
\text { Constructed Since 1990 }\end{array}$ \\
\hline $\begin{array}{l}\text { South } \\
\text { Africa }\end{array}$ & 63.8 & 68.8 \\
Ekurhuleni & 76.6 & 75.6 \\
\hline
\end{tabular}

Table 1 indicates the basic profile of the hotel economy of Ekurhuleni for 1990 and 2010. It reveals that in terms of actual numbers of hotels there is an overall net reduction of two hotel establishments. Nevertheless, between 1990 and 2010 the total room capacity nearly triples over this 20 year period. The analysis of the changing number of hotels in Ekurhuleni as a whole provides insight into the churning of the accommodation sector. Between 1990 and 201036 of the original 47 hotels ceased to exist as accommodation establishments. Only 11 of the original 47 hotels were in existence by 2010. During the 20 year study period 34 new hotel establishments were opened. These findings confirm a major turnover in the hotel property stock in Ekurhuleni between 1990 and 2010. Table 2 shows the remarkable overhaul of the local hotel stock. In total more than three-quarters of the 1990 hotel stock ceased to exist by 2010; this represents a much higher rate of change than that recorded for the country as a whole. Further, by 2010 three quarters of all hotels existing in Ekurhuleni were new property developments which had occurred post-1990, again a rate of renewal of the hotel stock which is shown as above the national average (Table 2).

Table 3: Ekurhuleni Hotels by Size Class 1990 and 2010

\begin{tabular}{lllllll}
\hline \multicolumn{5}{c}{$\mathbf{1 9 9 0}$} & \multicolumn{5}{c}{$\mathbf{2 0 1 0}$} \\
\hline & $1-50$ & $51-250$ & $>250$ & $1-50$ & $51-250$ & $>250$ \\
\hline Number & 42 & 5 & 0 & 18 & 24 & 3 \\
Percent & 89.4 & 10.6 & 0.0 & 40.0 & 53.3 & 6.7 \\
\hline
\end{tabular}

Table 4: Ekurhuleni Hotels by Star Rating of Quality Standard, 1990 and 2010

\begin{tabular}{lllllllll}
\hline & $\mathbf{1 9 9 0}$ & \multicolumn{7}{c}{$\mathbf{2 0 1 0}$} \\
& 1 & 2 & 3 & 1 & 2 & 3 & 4 & 5 \\
\hline Number & 39 & 6 & 2 & 16 & 2 & 15 & 9 & 3 \\
Percent & 83.0 & 12.8 & 4.2 & 35.6 & 4.4 & 33.3 & 20.0 & 6.7 \\
\hline
\end{tabular}


Tables 3 and 4 provide further data about the restructuring that occurred in the Ekurhuleni hotel economy between 1990 and 2010. Table 3 shows the distribution of hotels by different size categories. It discloses a major shift in the nature of the hotel economy with the demise of the small hotels which in 1990 comprised nearly 90 percent of the total hotel stock. The hollowing out of small hotels in Ekurhuleni is explained by the closure of many of the former low quality establishments typical of the standard of hotel in the late apartheid period. What has occurred between 1990 and 2010 is the appearance of new medium-sized hotels with between 51 and 250 rooms and of a number of large hotels with over 250 rooms. The growth in the proportion of medium-sized hotel accommodation establishments in Ekurhuleni parallels trends in the changing size structure of hotels for South Africa as a whole (Rogerson, 2013a, 2013b, 2013c).

Table 4 provides data on the number of hotel establishments by graded star rating. It confirms that a radical change has occurred in the quality standards of hotels in Ekurhuleni between 1990 and 2010. The most obvious shift is the disappearance and reduced share of the low-quality one class hotel establishments, the major share of which in 1990 was the liquordominated hotel. It should be noted, however, that between 1990 and 2010 there has been the appearance of a new form of one-star and two star budget accommodation by branded hotel chains which offer clean, convenient budget forms of accommodation which is line with international standards (Rogerson, 2013d). The upgrading in the quality standards of the hotel stock as a whole is revealed further by the finding that whereas in 1990 the category of three star hotels represented only 4 percent of total hotel stock by 201060 percent of hotels in the area were graded at least as three star quality establishments. Indeed, more than a quarter of hotels would now be classed as 4 or 5 star establishments offering high quality standards of accommodation (Table 4).

The growth of business tourism around the OR Tambo Airport has been the core driver for upgrading and expansion of the Ekurhuleni hotel economy between 1990 and 2010. The business tourism economy is a mix of local business tourism as well as an increasing share of regional African business tourism. New hotel developments around South Africa's major international airport have been accompanied by an expansion in conference venues and meeting rooms in the local cluster of business hotels. These major business hotels have been mainly developed by South African hotel chains, the most notable of which are Tsogo Sun, Protea, and City Lodge. A further post-1990 development in Ekurhuleni has been the result of changing legislation regarding casino developments which formerly were permitted only in the so-termed 'independent Homelands during the apartheid era. New casino legislation post1994 allowed the urbanisation of casino gambling. This resulted in the establishment in Ekurhuleni of two casino/entertainment hotel complexes, one close to the airport and the second on the outskirts of the metropolitan area at Brakpan. These casino complexes afforded a basis for developing leisure tourism alongside business tourism in Ekurhuleni.

Table 4: Ekurhuleni - Number of hotels and number of hotel rooms by centre

\begin{tabular}{lllll}
\hline Centre & $\mathbf{1 9 9 0}$ & 2010 & \\
& $\begin{array}{l}\text { Number of } \\
\text { hotels }\end{array}$ & $\begin{array}{l}\text { Number of } \\
\text { rooms }\end{array}$ & $\begin{array}{l}\text { Number of } \\
\text { Hotels }\end{array}$ & $\begin{array}{l}\text { Number of } \\
\text { rooms }\end{array}$ \\
\hline Alberton & 2 & 60 & 1 & 56 \\
Bapsfontein & 1 & 11 & 0 & 0 \\
Bedfordview & 0 & 0 & 3 & 192 \\
Benoni & 3 & 52 & 4 & 458 \\
Boksburg & 6 & 93 & 5 & 711 \\
Brakpan & 6 & 105 & 5 & 240
\end{tabular}




\begin{tabular}{lllll} 
Edenvale & 2 & 225 & 3 & 291 \\
Germiston & 14 & 277 & 7 & 222 \\
Kempton Park & 3 & 427 & 16 & 2149 \\
Modderfontein & 1 & 89 & 0 & 0 \\
Nigel & 2 & 42 & 0 & 0 \\
Springs & 7 & 158 & 1 & 40 \\
\hline Total & 47 & 1,539 & 45 & 4,386 \\
\hline
\end{tabular}

Table 5: Ekurhuleni - Number of hotels of different sizes by centre

\begin{tabular}{lllllll}
\hline & $\mathbf{1 9 9 0}$ & & & $\mathbf{2 0 1 0}$ & & \\
\hline Town & $\mathbf{1 - 5 0}$ & $\mathbf{5 1 - 2 5 0}$ & $\mathbf{2 5 0}$ & $\mathbf{1 - 5 0}$ & $\mathbf{5 1 - 2 5 0}$ & $>\mathbf{2 5 0}$ \\
\hline Alberton & 2 & 0 & 0 & 0 & 1 & 0 \\
Bapsfontein & 1 & 0 & 0 & 0 & 0 & 0 \\
Bedfordview & 0 & 0 & 0 & 1 & 2 & 0 \\
Benoni & 3 & 0 & 0 & 1 & 3 & 0 \\
Boksburg & 6 & 0 & 0 & 2 & 2 & 1 \\
Brakpan & 6 & 0 & 0 & 3 & 2 & 0 \\
Edenvale & 0 & 2 & 0 & 1 & 2 & 0 \\
Germiston & 14 & 0 & 0 & 6 & 1 & 0 \\
Kempton Park & 1 & 2 & 0 & 3 & 11 & 2 \\
Modderfontein & 0 & 1 & 0 & 0 & 0 & 0 \\
Nigel & 2 & 0 & 0 & 1 & 0 & 0 \\
Springs & 7 & 0 & 0 & 1 & 0 & 0 \\
\hline Total & 42 & 5 & 0 & 18 & 24 & 3 \\
\hline
\end{tabular}

Table 6: Ekurhuleni - Number of hotels and rooms of different quality standards by centre

\begin{tabular}{lllllllll}
\hline & 1990 & \multicolumn{7}{c}{ 2010 } \\
\hline Centre & 1 star & 2 star & 3 star & 1 star & 2 star & 3 star & 4 star & 5 star \\
\hline Alberton & 1 & 1 & 0 & 1 & 0 & 0 & 0 & 0 \\
Bapsfontein & 30 & 30 & 0 & 56 & 0 & 0 & 0 & 0 \\
& 1 & 0 & 0 & 0 & 0 & 0 & 0 & 0 \\
Bedfordview & 0 & 0 & 0 & 0 & 0 & 1 & 1 & 1 \\
& 0 & 0 & 0 & 0 & 0 & 120 & 56 & 16 \\
Benoni & 2 & 1 & 0 & 1 & 0 & 2 & 1 & 0 \\
& 33 & 19 & 0 & 58 & 0 & 187 & 240 & 0 \\
Boksburg & 6 & 0 & 0 & 0 & 0 & 3 & 2 & 0 \\
& 93 & 0 & 0 & 0 & 0 & 538 & 173 & 0 \\
Brakpan & 6 & 0 & 0 & 4 & 0 & 0 & 1 & 0 \\
& 105 & 0 & 0 & 135 & 0 & 0 & 105 & 0 \\
Edenvale & 0 & 2 & 0 & 2 & 0 & 1 & 0 & 0 \\
\multirow{5}{*}{ Germiston } & 0 & 225 & 0 & 72 & 0 & 219 & 0 & 0 \\
\multirow{5}{*}{ Kempton } & 13 & 1 & 0 & 5 & 1 & 0 & 0 & 1 \\
& 277 & 14 & 0 & 166 & 14 & 0 & 0 & 42 \\
Modderfontein & 1 & 0 & 2 & 3 & 1 & 7 & 4 & 1 \\
& 26 & 0 & 401 & 245 & 135 & 754 & 819 & 196 \\
Nigel & 0 & 1 & 0 & 0 & 0 & 0 & 0 & 0 \\
& 0 & 89 & 0 & 0 & 0 & 0 & 0 & 0 \\
& 2 & 0 & 0 & 0 & 0 & 0 & 0 & 0 \\
& 42 & 0 & 0 & 0 & 0 & 0 & 0 & 0
\end{tabular}




\begin{tabular}{lllllllll} 
Springs & 7 & 0 & 0 & 0 & 0 & 1 & 0 & 0 \\
& 158 & 0 & 0 & 0 & 0 & 40 & 0 & 0 \\
\hline
\end{tabular}

The growth and restructuring of the hotel economy of Ekurhuleni exhibits spatial differentiation and change. The spatial changes occurring in patterns of hotel location in Ekurhuleni can be understood in terms of the findings presented on Tables 4, 5 and 6 . These show respectively the distribution across Ekurhuleni for 11 centres of the absolute numbers of hotels and rooms (Table 4), the numbers of hotels by different sizes (Table 5) and the different quality of hotel establishments as indicated by star grading (Table 6). Several points can be highlighted. Table 4 reveals spatial restructuring as indexed by the absolute numbers of hotels and rooms. In 1990 the largest clusters of hotels are recorded in Germiston, Springs, Boksburg and Brakpan which together accounted for 33 hotels or 70 percent of all local hotels. Using the index of number of rooms the most important location is Kempton Park which incorporates the international airport. It is observed, however, that only three hotels existed there at this time providing a total of 427 rooms or 27.8 percent of total hotel rooms. The total of available hotel rooms in Ekurhuleni in 1990 was distributed widely across several of the old industrial and mining towns. By 2010 a number of changes can be observed. The most significant shift is the expansion and strengthening of the cluster of airport-related business hotels at Kempton Park and also in the neighbouring centres of Benoni, Boksburg and Edenvale. The growth of the Kempton Park cluster is particular striking; by 2010 this expanded to represent nearly half of all hotel rooms in Ekurhuleni. By contrast, considerable declines are recorded for Germiston, Springs and Nigel where a wave of hotel closures took place.

Table 5 provides further insight into these trends. It is clear that the growth of the airport cluster has been the consequence of the establishment of a number of medium-sized and large hotels. These developments mainly have occurred at Kempton Park and the surrounds of Benoni and Boksburg. The greatest shake-out and closures of small hotels are indicated for Germiston, Springs and Nigel all of which are locations of mining and old heavy industrial activities. Finally, Table 6 unpacks the shifts in quality standards of hotels for the 11 different centres. What is shown is that the demise of the hotel economy of Germiston, Springs and Nigel and other centres can be accounted for by the disappearance of the low quality one star and liquor-dominated hotel establishments. Upgrading of quality hotel stock is especially evident in and around the international airport where a cluster of new four and five star accommodation has been made available. Of note also is the appearance of a small number of quality and often small boutique hotel establishments in a number of locations across Ekurhuleni.

\section{Conclusion}

Research on the location of hotels is an expanding focus of urban tourism studies. This paper aims to extend the current international literature and scholarship which is dominated by investigations of hotel development and location patterns occurring in tourist-historic cities in Europe, Asia and the Middle East as well as global cities such as New York and Beijing. The focus of investigation was Ekurhuleni, one of South Africa's newest metropolitan areas and economically an area traditionally dominated by mining and industrial activity. This is a non-traditional tourism destination where until recently leisure tourism was not a component of the local economy. In terms of tourism development Ekurhuleni has expanded its share of business tourism as a result of its geographical location in South Africa's economic heartland. Importantly, business tourism has been driven by the location in Ekurhuleni of OR Tambo Airport, South Africa's major international gateway airport which has expanded considerably 
since the 1994 political transition and with developments linked to the hosting of the 2010 FIFA World Cup.

Between 1990 and 2010 this investigation shows that the local hotel economy of Ekurhuleni has been transformed. The analysis demonstrates that one critical element in restructuring has been the collapse of the low quality liquor dominated hotel which was numerically the major accommodation type of the pre-1990 period. The expanding business tourism economy resulted in new investments and hotel property developments in mediumsize and high quality four and five star hotel establishments. In terms of spatial organization these structural shifts have brought considerable change to the urban landscape. Growth has clustered geographically in and around the international airport which is the key contemporary locational influence for hotel location in this investigation. As compared to other South African cities this cluster of hotel developments around an airport is the most distinctive feature of the Ekurhuleni case study.

\section{Acknowledgments}

Thanks are due to Wendy Job for preparation of the accompanying figure. Useful inputs were made by Mabel Black, Teddy Norfolk and Skye Norfolk.

\section{References}

Adam, I. (2012). Hotel location decision-making in the Kumasi metropolis of Ghana: With whom and why? African Journal of Hospitality, Tourism and Leisure, 2.

Adam, I., (2013). Urban hotel development patterns in the Kumasi Metropolis, Ghana, Tourism Planning and Development, 10, pp. 85-98.

Adam, I. \& Amuquandoh, F.E. (2013). Hotel characteristics and location decisions in Kumasi Metropolis, Ghana, Tourism Geographies, DOI 10.1080/14616688.2012.762689

Adam, I \& Mensah, E.A. (2013). Perceived spatial agglomeration effects and hotel location choice, Anatolia, DOI 10.1080/13032917.2013.822818

Arbel, A. \& Pizam, A. (1977). Some determinants of urban hotel location: The tourists' inclinations, Journal of Travel Research, 15, pp. 18-22.

Ashworth, G.J. \& Tunbridge, J.E. (1990). The Tourist-Historic City. London: Belhaven.

Barke, M. \& France, L. (1986). Tourist accommodation in Spain 1971-1981. Tourism Management, 7, pp. 181-196.

Baum, J.A.C. \& Mezias, S.J. (1992). Localized competition and organizational failure in the Manhattan hotel industry, 1898-1990. Administrative Science Quarterly, 37, pp. 580- 604.

Bégin, S. (2000). The geography of a tourist business: Hotel distribution and urban development in Xiamen, China, Tourism Geographies, 2, pp. 448-471.

Bloch, R. (1993). Regenerating the East Rand; Promoting growth and opportunity in the South African industrial heartland, Unpublished Report for the Urban Foundation, Johannesburg.

Centre for Development and Enterprise (1997). The East Rand: Can South Africa's Workshop be revived?. Johannesburg, CDE.

Department of Tourism (2011). National Tourism Sector Strategy. Pretoria, National Department of Tourism.

Dökmeci, V. \& Balta, N. (1999). The evolution and distribution of hotels in Istanbul, European Planning Studies, 7, pp. 99-109.

Egan, D. J. \& Nield, K. (2000). Towards a theory of intraurban hotel location, Urban Studies, 37, pp. 611-621.

Ernst \& Young (2011). Sub-Saharan Africa Hospitality Overview. Report prepared for the World Bank, Washington DC. 
Ferreira, S. \& Boshoff, A. (2014). Post-2010 FIFA Soccer World Cup: Oversupply and location of luxury hotel rooms in Cape Town, Current Issues in Tourism, 17 (2), pp. 180198.

Hancock, T. (2011) Aerotropolis concept at the heart of Ekurhuleni's new development thrust, Engineering News, 14 October.

Jansen-Verbeke, M. (1986) Inner-city tourism: Resources, tourist and promoters, Annals of Tourism Research, 13, pp. 79-100.

Law, C. M. (1992). Urban tourism and its contribution to economic regeneration, Urban Studies, 29, pp. 599-618.

Law, C.M. (1993). Urban tourism: Attracting visitors to large cities. London, Mansell.

McNeill, D. (2009). The airport hotel as business space. Geografiska Annaler B, 91, pp. 219228.

Medlik, S. \& Ingram, H. (2000). The Business of Hotels, Oxford, Butterworth-Heinemann.

Oppermann, M. Din, K. H. \& Amri, S. Z. (1996). Urban hotel location and evolution in a developing country: The case of Kuala Lumpur Malaysia. Tourism Recreation Research, 2, pp. 55-63.

Niewiadomski, P. (2013a), Towards an economic-geographical approach to the globalization of the hotel industry, Tourism Geographies, DOI:10.1080/14616688.2013.867528

Niewiadomski, P. (2013b). The globalization of the hotel industry and the variety of emerging capitalisms in Central and Eastern Europe, European Urban and Regional Studies, DOI: 10.1177/0969776413502658.

Nunkoo, R., Seetanah, B. \& Sannassee, R.V. (eds.) (2014). Conference Proceedings $4^{\text {th }}$ Advances in Hospitality \& Tourism Marketing \& Management Conference 25-27 June, Mauritius, Port Louis: University of Mauritius.

Pearce, D.G. \& Grimmeau, J-P. (1995). The spatial structure of tourist accommodation and hotel demand in Spain. Geoforum, 16, pp. 37-50.

Peleggi, M. (2012). The social and material life of colonial hotels: comfort zones as contact zones in British Colombo and Singapore, ca. 1870-1930. Journal of Social History, 46, 124-153.

Raitz, K. \& Jones, J.P. (1988). The city hotel as landscape artefact and community symbol. Journal of Cultural Geography, 9, pp. 17-36.

Ritter, W. (1986). Hotel location in big cities. In F. Vetter (ed.), Big City Tourism, pp. 355364. Berlin: Reimer Verlag.

Roberts, S. (ed) (2006): Sustainable Manufacturing: The Case of South Africa \& Ekurhuleni, Cape Town, Juta.

Rogerson, C.M. (2005). Local development planning in Ekurhuleni: emerging policy and strategy in South Africa's newest metropolitan area. Africa Insight, 35 (4), pp. 72-79.

Rogerson, C.M. (2006). From national industrial workshop to 'rustbelt'?: Restructuring the manufacturing economy of Ekurhuleni 1980-1999. In S. Roberts (ed) Sustainable Manufacturing: The Case of South Africa \& Ekurhuleni, pp. 112-120. Cape Town, Juta.

Rogerson, C.M. (2011). From liquor to leisure: The changing South African hotel industry 1928-1968. Urban Forum, 22, pp. 379-394.

Rogerson, C.M. \& Rogerson, J.M. (2011). Tourism research within the Southern African Development Community: Production and consumption in academic journals, 2000-2010, Tourism Review International, 15 (1/2), pp. 213-222. DOI: 10.3727/154427211X13139345302487

Rogerson, C.M. \& Visser, G. eds. (2004) Tourism and development issues in contemporary South Africa. Pretoria, Africa Institute of South Africa.

Rogerson, C.M. \& Visser, G. eds. (2007). Urban tourism in the developing world: The South African experience. New Brunswick, NJ: Transaction Press. 
Rogerson, C. M. \& Visser, G. (2011). Rethinking South African urban tourism research. Tourism Review International, 15 (1/2), pp. 77-90.

Rogerson, J.M. (2010). The boutique hotel industry in South Africa: definition, scope and organization, Urban Forum, 21, pp. 425-439.

Rogerson, J.M. (2011a). The limited services hotel in South Africa: the growth of City Lodge, Urban Forum, 22, pp. 343-361.

Rogerson, J.M. (2011b). The changing all-suite hotel in South Africa: from 'extended stay' to African condo hotel, Tourism Review International, 15 (1/2), pp. 107-121.

Rogerson, J.M. (2012a). The changing location of hotels in South Africa's coastal cities, Urban Forum, 23, pp. 73-91.

Rogerson, J.M. (2012b). Hotels as a property asset class: international and South African trends. Africa Insight, 42, pp. 200-211.

Rogerson, J.M. (2013a). Size matters in the African hotel industry: The case of South Africa. African Journal for Physical, Health Education, Recreation and Dance, 19 (Supplement 2): pp. 217-233.

Rogerson J.M. (2013b). Reconfiguring South Africa’s hotel industry 1990-2010: Structure, segmentation, and spatial transformation, Applied Geography, 36, pp. 59-68.

Rogerson, J. M. (2013c). The economic geography of South Africa's hotel industry 1990 to 2010, Urban Forum, 24 (3), pp. 425-446.

Rogerson, J.M. (2013d). Market segmentation and the changing budget hotel industry in South Africa. Urbani Izziv, 24 (2), pp. 112-123.

Rogerson J.M. (2013e). Urban tourism and the changing structure of the hotel economy in South Africa, African Journal for Physical, Health Education, Recreation and Dance, Supplement 2 (September), pp. 39-54.

Rogerson, J.M. (2014a). Unpacking the growth of hotel chains in Africa: Enterprises and patterns. Mediterranean Journal of Social Sciences, 5 (14), pp. 135-146.

Rogerson, J.M. (2014b). Hotel location in Africa's world class city: The case of Johannesburg, South Africa. Bulletin of Geography: Socio-Economic Series, 25,pp. 181196.

Rogerson, J.M., \& Kotze, N. (2011). Market segmentation and the changing South African hotel industry 1990 to 2010. African Journal of Business Management, 5, pp. 1352313533.

Rogerson, J.M. \& Sims, S.R. (2012). The greening of urban hotels in South Africa: Evidence from Gauteng. Urban Forum, 23, pp. 391-407

Shoval, N., (2006). The geography of hotels in cities: An empirical validation of a forgotten model, Tourism Geographies, 8, pp. 56-75.

Shoval, ,N. \& Cohen-Hattab, K. (2001). Urban hotel development patterns in the face of political shifts, Annals of Tourism Research, 28, pp. 908-925.

Shoval, N. Kercher, B., Ng, E. \& Birenboim, A. (2011) Hotel location and tourist activity in cities. Annals of Tourism Research, 38, pp. 1594-1612.

Smith, N. (2013). Ekurhuleni aerotropolis poised for takeoff. Business Day, 29 August.

South African Cities Network (2011). Towards Resilient Cities: A Reflection on the First Decade of a Democratic and Transformed Local Government in South Africa 2001-2010, Johannesburg, SACN.

Timothy, D. J. \& Teye, V. B. (2009). Tourism and the Lodging Sector. London: ButterworthHeinemann.

Timothy, D.J. \& Wall, G. (1995). Tourist accommodation in an Asian historic city, Journal of Tourism Studies, 6, pp. 63-73.

Urtasun, A. \& Gutiérrez, I. (2006). Hotel location in tourism cities: Madrid 1936-1998, Annals of Tourism Research, 33, pp. 382-402. 
Van Doren, C.S. \& Gustke, L.D. (1982). Spatial analysis of the U.S. lodging industry, 19631977. Annals of Tourism Research, 9, pp. 543-563.

Visser, G. (2013) Looking beyond the urban poor in South Africa: The new terra incognita for urban geography? Canadian Journal of African Studies, 47 (1), pp. 75-93. DOI: 10.1080/1080.00083968.2013.770593

Visser, G. \& Rogerson, C.M. (2014) Reflections on 25 years of Urban Forum. Urban Forum, 25 (1), pp. 1-11. DOI: 10.1007/s12132-014-9227-3

Walker, G.S. (1977). The History of the South African hotel industry with special reference to the role of the Hotel Board. Thesis submitted for the National Diploma in Hotel Management, Johannesburg.

Wall, G., Dudycha, D., \& Hutchinson, J. (1985). Point pattern analyses of accommodation in Toronto. Annals of Tourism Research, 12, pp. 603-618.

Williams, A.M. (2014). Introduction: producing tourism and tourism spaces. In A.A. Lew, C.M. Hall \& A.M. Williams (eds.), The Wiley Blackwell Companion to Tourism, pp. 101106. Chichester: John Wiley

Yang,Y. Lui, H. \& Law, R. (2014). Theoretical, empirical, and operational models in hotel location research. International Journal of Hospitality Management, 36, pp. 209-220.

Yang, Y., Wong, K.K.F. \& Wang, T. (2012). How do hotels choose their location?: Evidence from hotels in Beijing, International Journal of Hospitality Management, 31, pp. 675-685.

Zhang, H.Q. Guillet, B.D. \& Gao, W., 2012: What Determines Multinational Hotel Groups' Locational Investment Choice in China? International Journal of Hospitality Management, 31, pp. 350-359. 